Hycenodon by which the internal nostrils are displaced as far backwards as those of a crocodile. They remark that "there is no other feature in the teeth or skeleton of the hyænodonts to suggest amphibious habits". They also point out that Hyonodon cannot have fed on ants like the existing ant bear (Myrmecophaga), which exhibits a nearly similar arrangement of the palate.

The beautifully preserved skeletons of Canidæ or dogs are especially interesting, because they show that in Oligocene times the family was not so completely distinguished from other Carnivora as it is at present, while one genus, Daphoenus, seems to be the common ancestor of at least three distinct groups of modern Canidæ. The smaller Oligocene dogs must have looked much like civets.

There are very few Mustelidæ in the White River formation. This family seems to have been much more characteristic of the Old World than of the New World during Oligocene times. Of the
Felidæ, no true cats have bəen found in North America bəfore the Pliocene, but the sabre-tooth cats or Machairodontinæ are well represented in the White River formation. They are all much smaller than the familiar 'sabre-toothed tiger' of later date, but it is interesting to observe that the articulation of the lower jaw in the Oligosene genera is as completely adapted for the wide opening of the mouth as it is in the latest Pleistocene genera. There is no doubt that the sabreshaped canines were used for stabbing; and one skull of Nimravus in the museum of the Dakota State School of Mines exhibits a large gash in the brain-case that was evidently made by such a stab.

From this brief summary it is clear that Prof. Scott and Prof. Jepsen are doing much more than providing technical descriptions of the fossils. They are publishing an illuminating treatise on Oligocene mammals, of which the succeeding parts will be eagerly awaited.

A. S. W.

\title{
Daniel Gabriel Fahrenheit (I686-I736)
}

A MONG the many improvers of the thermoA meter in the eighteenth century, none laboured more assiduously or successfully than Daniel Gabriel Fahrenheit, the German natural philosopher and instrument maker who died in Holland at the early age of fifty years on September 16, 1736. His work was done at a time when the physical and medical sciences were making rapid advances, and there was great need for thermometers of good construction and furnished with a standard scale which could be used for comparisons. It was this need that Fahrenheit met. He was not the first to make thermometers, the first to use alcohol or mercury, or to devise scales with fixed points, but his improvements were such as to make his thermometers known all the world over, and though to-day it is generally recognized that the universal use of the centigrade scale would be a great advantage, the Fahrenheit thermometer seems likely to remain in use for many years yet.

For nearly a century before Fahrenheit's time, men of science had been using thermoscopes and thermometers, and a grand array of names is associated with their early history. Galileo, Boyle, Huygens, Hooke, Halley and others all contributed to the progress of thermometry. Doctors were especially interested in thermometers by which the temperature of human beings and animals could be taken, while natural philosophers required thermometers as much as barometers. The term 'thermometer' is first mentioned by the French
Jesuit, Father Leurechon (1591-1670), in his "Recreation mathematique" published in 1624 . The early instruments were subject to changes in atmospheric pressure and were really 'barothermoscopes'. Ferdinand II, Grand Duke of Tuscany (1610-70), founder of the Accademia del Cimento at Florence, was the first to produce a thermometer unaffected by atmospheric pressure.

There were all sorts of ideas regarding the graduation of thermometers. In 1665 Boyle suggested the freezing point of aniseed oil, and Huygens in the same year suggested as fixed points the freezing point and boiling point of water. Snow in very cold weather, the greatest heat in summer and melting butter were also proposed for definite temperatures. There were also many suggestions regarding scales, about a score of scales being used in the eighteenth century, of which, however, those due to Fahrenheit, Réaumur and Celsuis, or perhaps more correctly Martin Strömer, alone survived.

It is well known that Fahrenheit was the first to bring the mercurial thermometer into general use, that he devised his well-known scale about 1714, and that he described his method of making thermometers in five short papers in Latin to the Royal Society in 1724, but it is not generally known how he came to be an instrument maker. The bicentenary of his death, however, has led to the publication of a biographical memoir in the Transactions of the Royal Academy of Sciences of 
Amsterdam, the authors of which, E. Cohen and W. A. T. Cohen-de Meester, add a great deal to our knowledge of Fahrenheit's personal history. This memoir shows Fahrenheit in a most pleasing light, gleaning information from many sources, writing and lecturing on such things as hydrostatics, optics and chemistry, and consorting with some of the most learned men of his time. Of special interest in this memoir are the references to some letters not long ago discovered in Leningrad. In one of these, written on April 17, 1729, to the famous physician Boerhaave, Fahrenheit tells of a visit in 1708 to the Danish astronomer Römer, whom he found placing thermometers in a mixture of ice and water and in blood-warm water. Inspired by his contact with Römer, Aahrenheit began to read about barometers and thermometers and studied the memoirs of Maraldi, de La Hire and Amontons in the publications of the Paris Academy of Sciences. Of the writings of British physicists, he knew only of Boyle's works, so far as they had been translated into Latin, as it was not until his visit to England and his election into the Royal Society in 1724 that he studied English.
Born in Dantzig on May 24, 1686, Fahrenheit was the eldest of a family of three boys and two girls, who were left orphans in August 1701 by the accidental death of both father and mother. $\mathrm{He}$ was sent by his guardian to Amsterdam to a merchant's house to learn business, and as a young man made journeys into Denmark, Sweden, Germany and Russia, probably settling finally in 1715 in Amsterdam, where by his lectures he stimulated the study of physical science and where he constructed the thermometers for which he will always be remembered. In 1736 he secured a patent for a mill for draining purposes but did not live to reap any benefit therefrom. His death took place at The Hague, and four days later he was buried in the Kloster kirke, the register of which contains the entry "Am 20 September 1736 am Tage begraben in dem Gewölbe unter dem Chor Daniel Gabriel Fahrenheit. Für Miete des Grabes und zwei Läuten 18 Gulden".

The memoir on Fahrenheit to which reference has been made above contains portraits of several of his most celebrated contemporaries, including Boerhaave, Römer, s'Gravesande, Musschenbroek and Nieuwentyt, but none of Fahrenheit himself.

\section{Obituary}

\section{Mr. William Rintoul, O.B.E.}

$\mathrm{M}^{\mathrm{R}}$ R. WILLIAM RINTOUL died at the age of sixty-six years at his home in Ardrossan, Ayrshire, on August 25, after nearly a year's illness. His career had been a remarkable one, and began in Glasgow, where he was educated and received in Anderson's College his scientific training. In the late 'eighties there were (as there are even now) few sehools of analytical chemistry, so that Mr. R. R. Tatlock not only filled the post of city analyst but also himself lectured and had a staff of lecturers on chemistry and physics to students many of whom afterwards became his assistants and later occupied important positions in the chemical profession. Ramsay was one of them.

After a short time as an assistant, Rintoul lectured to Tatlock's students until in 1891 a post of chemist offered in a paint manufacturer's near London, where he got chemical and works experience. After three years there he went in 1894 to the Royal Gunpowder Factory as a chemist in the laboratory, later becoming chemist-in-charge of the manufacture of nitroglycerme, and for two years before he resigned he was chief chemist in the laboratory.

At this time the Royal Gunpowder Factory under Sir Frederic Nathan as superintendent and Mr. James Thomson as manager led the explosives industry in Great Britain in organization, in safety precautions and in the invention of new processes and plant. Rintoul, naturally inventive and of remarkable manual skill, did his full share of which the displacement process for the manufacture of nitroglycerine is an example. This process improved the manufacture of that explosive economically in that no high buildings were required to house the plant and also from the point of view of safety, as the nitroglycerine was removed (by upward displacement) from its acid mixture as soon as it had been formed and was sent at once for its preliminary washing, instead of being left to separate in bulk in an acid, and more or less dangerous, state. At this time also he was co-inventor with Robertson of a process and plant for the recovery of acetone, the solvent used in the manufacture of cordite.

Accompanying Sir Frederic Nathan to Nobel's Explosives Company (now part of Imperial Chemical Industries, Ltd.) at Ardeer in Ayrshire in 1909 as chief chemist, he became research manager there and devoted himself to the organization of the laboratories and erection of many new ones. His policy had several features which have been commended by thers in like position, as for example, the provision that all chemists, whether destined for research or plant, should first undergo a thorough training in analytical chemical methods, the insistence on a good system of documentation of reports and of published work, the installation of physical methods of testing explosives and close contact with the universities. 